\title{
Ludwig Heilmeyer
}

Prof. Ludwig Heilmeyer who died unexpectedly on September 6 at the age of 70, was particularly interested in haematology. Already many years ago, when he was Associate Professor of Medicine at the Medizinische Universitätsklinik in Jena, he published his studies on Iron therapy, Serum iron and Iron Deficiency.

Later, when he held the chair of Internal Medicine at the University of Freiburg i.Br., he was the author of the outstanding Atlas der Klinischen Hämatologie (with Begeman) and edited the comprehensive Handbuch der gesamten Hämatologie. Since Acta Haematologica were founded (1948) Heilmeyer was very active as one of our Contributing Editors. A number of his important papers appeared in our journal.

The International Society of Haematology had elected Heilmeyer

President for the meeting which will take place in München 1970.

His untimely death is deeply felt.

The Editors-in-Chief and the Publisher

Photo: Willy Pragher. Freiburg i.Br. 